\title{
ENZYMATIC HYDROLYSIS OF LIGNOCELLULOSE FOR BIOETHANOL PRODUCTION
}

\author{
Linda Rozenfelde ${ }^{1, \#}$, Māris Puḳe ${ }^{2}$, Irēna Krūma ${ }^{2}$, leva Poppele ${ }^{1,3}$, Natạjja Matjuškova ${ }^{1,3}$, \\ Nikolajs Vedernikovs ${ }^{2}$, and Alexander Rapoport ${ }^{1}$ \\ ${ }^{1}$ Institute of Microbiology and Biotechnology, University of Latvia, 4 Kronvalda Blvd., Riga, LV-1586, LATVIA \\ ${ }^{2}$ Laboratory of Polysaccharides, Latvian State Institute of Wood Chemistry, 27 Dzērbenes Str., Riga, LV-1006, LATVIA \\ ${ }^{3}$ Faculty of Biology, University of Latvia, 4 Kronvald Blvd., Riga, LV-1586, LATVIA \\ \# Corresponding author, lindyr@inbox.Iv
}

Contributed by Alexander Rapoport

The effect of temperature, time and amount of enzyme on hydrolysis of wheat straw lignocellulose remaining after furfural production was studied. The residual substrate was subjected to enzymatic hydrolysis at different temperatures $-45^{\circ} \mathrm{C}, 50^{\circ} \mathrm{C}$ and $55^{\circ} \mathrm{C}$. Hydrolysis time was 72 hours, and samples were taken every 24 hours. The maximum glucose yield $(76.5 \%$ of the theoretically possible) was reached when hydrolysis temperature $50^{\circ} \mathrm{C}$ was used. The production rate of glucose increased with a hydrolysis period of time. The yield of glucose significantly depended on the ratio of enzyme to substrate.

Key words: bioethanol, enzymatic hydrolysis, wheat straw.

\section{INTRODUCTION}

Over the last 25 years, renewable, domestic sources of fuels and chemicals have become highly important (Ladisch and Dyck, 1979). For example, bioethanol is a potential alternative to petroleum-derived transportation fuels, because bioethanol has a higher octane number, broader flammability limits, higher flame speeds and higher heat of vaporisation (Neelakandan and Usharani, 2009; de Oliveria et al., 2005; Grad, 2006; Balat, 2007; Wheals et al., 2009; Govindaswamy and Vane, 2007). Biofuels can be produced from a variety of feedstocks, such as plant oils, sugar beets, cereals, organic waste and the processing of biomass. Biological raw material that contains sugar or can be converted into sugar (starch, cellulose) can be used for the production of bioethanol (Malca and Freire, 2006). There are three types of bioethanol feedstocks: (a) sucrose-containing feedstocks (e.g. sugar beet, sweet sorghum, and sugar cane), (b) starchy materials (e.g. wheat, maize, and barley), and (c) lignocellulosic biomass (e.g. wood, straw, and grasses). All of these materials can be utilised for bioethanol production (Linoj Kumar et al., 2006). Bioconversion of straw to bioethanol is an attractive alternative to conventional fuel ethanol production from grain (Ballesteros et al., 2006). In such production, technologies use inexpensive renewable resources that cannot be utilised in the food industry (Calinescu et al., 2012; Escobar et al., 2012). Wheat straw is a very promising substrate because it is the largest biomass feedstock in Europe and the second largest in the world after rice straw (Kim and Dale, 2004). Also, it is known that about $21 \%$ of the world's food is produced from wheat crop and it is necessary to increase its production to satisfy the growing demand of human consumption; therefore, wheat straw has a great potential as feedstock in the future (Ortiz et al., 2008).

However, lignocellulose carries the structure of the plant biomass and is difficult substrate to degrade. Therefore, thermo-chemical and enzymatic pretreatments are necessary for lignocellulose degradation to make the monomers available for further processing. A number of pretreatment methods have been developed and used for wheat straw biomass. The pretreatment is classified into physical, physico-chemi$\mathrm{cal}$, chemical, and biological processes. The main purpose for pretreatment is to improve the rate of production and total yield of sugar at the hydrolysis step (Hendriks and Zeeman, 2009). The hydrolysis step is necessary for the conversion of biomass into monomer sugars for subsequent fermentation into bioethanol (Van Dyk and Pletschke, 2012). Hydrolysis can be carried out by acids or enzymes. Enzymatic hydrolysis has several advantages over the use of acid, because acid hydrolysis has relatively low yield, no selectivity and it needs a high process temperature $\left(140-160{ }^{\circ} \mathrm{C}\right)$ and neutralisation after hydrolysis (Taherzadeh and Karimi, 2007). Enzymatic hydrolysis of cellulose is catalysed by a class of enzymes called cellulases. These enzymes can be produced by fungi or bacteria. However, most research on commercial scale production of cellulases is focused on fungi, since the majority of cellulase-produc- 
ing bacteria are anaerobes with a very low growth rate. Three groups of enzymes are needed for liberation of sugars from cellulose - endo-glucanases, exo-glucanases (cellobiohydrolases), and $\beta$-glucosidases. Endo-glucanase splits the long chains of cellulose to shorter molecules. Exoglucanase removes units of two linked glucose molecules named cellobiose from the free chain-ends ends and then cellobiose is cleaved into glucose monomers by $\beta$-glucosidase (Bhat and Bhat, 1997; Juhisz et al., 2005). There are several factors influencing the efficiency of hydrolysis. The aim of this our study was to identify the optimum conditions of enzymatic hydrolysis of wheat straw lignocellulose that remains after furfural production.

\section{MATERIALS AND METHODS}

Material and pre-treatment. Wheat straw was purchased from a local district of Saldus. The studies were carried out using a new bench scale reactor system and unique pretreatment technology (Vedernikov, 2008). The diameter of the main reactor of the bench equipment was $110 \mathrm{~mm}$, height $1450 \mathrm{~mm}$, volume 13.7 litres, and the maximally permitted steam pressure was 1.2 $\mathrm{MPa}$. The raw material was mixed with the corresponding amount of the catalyst and treated with steam flow in steam temperature $-150{ }^{\circ} \mathrm{C}$ in the described reactor. Sulphuric acid in the amount of $3 \%$ was used as a catalyst in the pre-treatment process. The length of process was 60 minutes. After pretreatment, wheat straw was washed four times for 10 minutes at temperature $110{ }^{\circ} \mathrm{C}$ and then dried at $25{ }^{\circ} \mathrm{C}$. After drying samples were ground to average size of $2.5 \mathrm{~mm}$.

Enzymatic hydrolysis. The pretreated wheat straw was subjected to hydrolysis with commercial enzymes Accellerase 1500 and Accellerase $\mathrm{XC}$ obtained from DuPont ${ }^{\mathrm{TM}} \mathrm{Ge}-$ nencor ${ }^{\circledR}$ Science. The hydrolysis reactions were performed in $0.5 \mathrm{M}$ citrate buffer $(\mathrm{pH} 5.0)$ at $45^{\circ} \mathrm{C}, 50^{\circ} \mathrm{C}$, and $55^{\circ} \mathrm{C}$ for $72 \mathrm{~h}$ with shaking $(80 \mathrm{rpm})$ and sample loading $0.6 \mathrm{~g} / 10$ $\mathrm{ml}$ buffer. Concentrations of $0.095 \mathrm{ml}, 0.125 \mathrm{ml}, 0.25 \mathrm{ml}$, and $0.5 \mathrm{ml}$ Accellerase $1500 / 10 \mathrm{ml}$ buffer were used for experiments at temperature $45{ }^{\circ} \mathrm{C}$ and $50{ }^{\circ} \mathrm{C}$. Concentrations of Accellerase 1500 at $0.25 \mathrm{ml}$ and $0.5 \mathrm{ml}$ per $10 \mathrm{ml}$ buffer were used for experiments at temperature $55^{\circ} \mathrm{C}$. In experiments with Accellerase $\mathrm{XC}$ as an additional enzyme, the concentration of $0.085 \mathrm{ml} / 10 \mathrm{ml}$ buffer was used.

When extra adding of enzymes was done, then different concentrations of enzymes were used:

1) $0.25 \mathrm{ml}$ Accellerase 1500 at the begining of hydrolysis and then additionally $0.25 \mathrm{ml}$ of Accellerase 1500 after $48 \mathrm{~h}$ after start of the process; 2) $0.25 \mathrm{ml}$ Accellerase 1500 and $0.17 \mathrm{ml}$ Accellerase $\mathrm{XC}$ at the begining of hydrolysis and then additionally $0.17 \mathrm{ml}$ of Accellerase XC after $48 \mathrm{~h}$; 3) $0.25 \mathrm{ml}$ Accellerase 1500 and $0.17 \mathrm{ml}$ Accellerase $\mathrm{XC}$ at the begining of hydrolysis and then additionally $0.25 \mathrm{ml}$ Accellerase 1500 and $0.17 \mathrm{ml}$ Accellerase XC after $48 \mathrm{~h}$.

Determination of sugar. Glucose content was determined in samples every 24 hours. The concentration of reducing sugars was determined spectrofotometrically by the DNS method (Mosier et al., 2005). A total of five experiments were performed for each parameter.

\section{RESULTS}

Enzymatic hydrolysis of pretreated wheat straw was carried out by adding two types of cellulases - Accellerase 1500 and Accellerase XC. Various parameters such as hydrolysis time, temperature and amount of enzyme were tested for the purpose of achieving maximum saccharification of wheat straw lignocellulose (LC) remaining after furfural production.

Firstly the effect of time on the enzymatic hydrolysis was studied. The pre-treated wheat straw LC was mixed with enzymes and hydrolysed for 72 hours. The concentration of released reducing sugar was measured every $24 \mathrm{~h}$. The results showed that the amount of released glucose increased with enzymatic reaction time (Tables 1,2 ). Maximum con-

Table 1

GLUCOSE YIELD AFTER ENZYMATIC HYDROLYSIS WITH ACCELLERASE 1500 AT TEMPERATURES $45^{\circ} \mathrm{C}, 50{ }^{\circ} \mathrm{C}$, AND $55^{\circ} \mathrm{C}$

\begin{tabular}{c|c|c|c|c|c|c}
\hline & Time $(\mathrm{h})$ & 5 & 10 & 24 & 48 & 72 \\
\hline $\begin{array}{c}\text { Amount of } \\
\text { Accellerase } \\
1500(\mathrm{ml})\end{array}$ & $\begin{array}{c}\text { Temperature of } \\
\text { hydrolysis }\left({ }^{\circ} \mathrm{C}\right)\end{array}$ & & \multicolumn{5}{c}{ Glucose yield $(\mathrm{mg} / \mathrm{ml})$} \\
\hline 0.5 & 45 & 14.4 & 17.7 & 24.9 & 25.6 & 26.4 \\
0.25 & & 13.5 & 16.1 & 23.1 & 24.6 & 25.2 \\
0.125 & & 11.9 & 15.8 & 20.6 & 22.4 & 23.6 \\
0.095 & & 7.7 & 14.3 & 18.1 & 18.8 & 18.9 \\
\hline 0.5 & 50 & 13.1 & 21.4 & 25.8 & 27.5 & 28.6 \\
0.25 & & 12.9 & 20.3 & 26.4 & 27.5 & 28.4 \\
0.125 & & 12.5 & 16.9 & 21.9 & 22.4 & 22.9 \\
0.095 & & 10.8 & 14.4 & 17.4 & 20.1 & 20.7 \\
\hline 0.5 & \multirow{2}{*}{55} & 14.9 & 19.5 & 23.1 & 25.7 & 26.5 \\
0.25 & & 13.1 & 17.7 & 19.7 & 23.6 & 24.7
\end{tabular}

Table 2

GLUCOSE YIELD AFTER ENZYMATIC HYDROLYSIS WITH ACCELLERASE 1500 AND ACCELLERASE XC AT TEMPERATURES $45{ }^{\circ} \mathrm{C}, 50{ }^{\circ} \mathrm{C}$, AND $55^{\circ} \mathrm{C}$

\begin{tabular}{c|c|c|c|c|c|c}
\hline & Time (h) & 5 & 10 & 24 & 48 & 72 \\
\hline $\begin{array}{c}\text { Amount of } \\
\text { Accellerase } \\
1500(\mathrm{ml})\end{array}$ & $\begin{array}{c}\text { Temperature of } \\
\text { hydrolysis }\left({ }^{\circ} \mathrm{C}\right)\end{array}$ & \multicolumn{5}{c}{ Glucose yield (mg/ml) } \\
\hline 0.5 & 45 & 16.2 & 19.7 & 25.6 & 26.5 & 27.2 \\
0.25 & & 14.5 & 17.9 & 23.8 & 24.8 & 25.6 \\
0.125 & & 11.9 & 14.3 & 23.1 & 23.6 & 24.4 \\
0.095 & & 10.6 & 13.3 & 20.4 & 21.6 & 22.5 \\
\hline 0.5 & 50 & 12.6 & 19.6 & 25.8 & 27.7 & 27.9 \\
0.25 & & 11.2 & 19.9 & 25 & 27.2 & 28.1 \\
0.125 & & 9.7 & 18.8 & 22.5 & 25.2 & 24.8 \\
0.095 & & 8.3 & 12.3 & 20.8 & 22.3 & 22.7 \\
\hline 0.5 & 55 & 16.6 & 20.3 & 24.2 & 26.5 & 27.4 \\
0.25 & & 15.1 & 19.4 & 21.9 & 24.6 & 25.5
\end{tabular}


centration of glucose in all samples was reached after $72 \mathrm{~h}$ of enzymatic hydrolysis. The maximum saccharification rate was $28.6 \mathrm{mg} / \mathrm{ml}$ when $0.5 \mathrm{ml}$ Accellerase 1500 was used and $28.1 \mathrm{mg} / \mathrm{ml}$ when Accellerase XC was added. The concentration of glucose rapidly increased during first 24 hours of hydrolysis and subsequently increased more slowly, perhaps due to inhibition of enzyme activity by the accumulated hydrolysis products.

Further we determined the effect of temperature on the efficiency of hydrolysis of wheat straw LC. Three different temperatures were used for hydrolysis reaction $-45{ }^{\circ} \mathrm{C}$, $50{ }^{\circ} \mathrm{C}$, and $55^{\circ} \mathrm{C}$. Tables 1 and 2 show that the highest glucose yield was obtained with hydrolysis temperature $50{ }^{\circ} \mathrm{C}$. When temperature $45^{\circ} \mathrm{C}$ was used, maximum glucose yield was lower by about $2.2 \mathrm{mg} / \mathrm{ml}(26,4 \mathrm{mg} / \mathrm{ml})$ than by hydrolysis at $50{ }^{\circ} \mathrm{C}$. At temperature $55^{\circ} \mathrm{C}$ the yield was lower by about $2.1 \mathrm{mg} / \mathrm{ml}(26,5 \mathrm{mg} / \mathrm{ml})$ than by hydrolysis at $50{ }^{\circ} \mathrm{C}$.

The effect of concentration of added enzymes was also investigated. Concentrations of $0.095 \mathrm{ml}, 0.125 \mathrm{ml}, 0.25 \mathrm{ml}$, and $0.5 \mathrm{ml}$ Accellerase 1500/10 $\mathrm{ml}$ buffer were used for experiments at temperature $45{ }^{\circ} \mathrm{C}$ and $50{ }^{\circ} \mathrm{C}$. The results showed that increasing concentration of enzymes increased glucose yield, but concentrations of $0.25 \mathrm{ml}$ and $0.5 \mathrm{ml}$ gave almost the same result after 72 hours of hydrolysis $28.4 \mathrm{mg} / \mathrm{ml}$ and $28.6 \mathrm{mg} / \mathrm{ml}$, respectively.

Addition of Accellerase XC improved enzymatic hydrolysis and the total glucose yield, compared to that in samples in which smaller amounts of enzyme Accellerase 1500 were used $(0.125 \mathrm{ml}$ and $0.095 \mathrm{ml})$. As the result, at the optimum temperature of hydrolysis $\left(50{ }^{\circ} \mathrm{C}\right)$, final glucose yield was approximately by $2 \mathrm{mg} / \mathrm{ml}$ higher than in the case of samples with only Accelerase 1500. For the samples in which $0.5 \mathrm{ml}$ and $0.25 \mathrm{ml}$ Accellerase 1500 were used, the results were practically the same with or without the use of Accellerase XC. Addition of Accelerase XC gave positive effects also at all concentrations of the main enzyme at lower and higher then optimum temperatures of hydrolysis (at $45{ }^{\circ} \mathrm{C}$ and $55^{\circ} \mathrm{C}$ ).
The next series of experiments was conducted to determine if extra addition of enzymes after 48 hours from the beginning of enzymatic treatment could increase glucose yield after hydrolysis. The results showed that extra addition of enzymes did not lead to increase of glucose yield in the conditions implemented in our experiments (Fig. 1).

\section{DISCUSSION}

Experts have predicted that oil resources can be completely extracted during the next 40-50 years, and that its substitution by renewable cellulose-containing products of agriculture is one of the most important problems for current biotechnological science (Kerr, 1998; Grad, 2006; Wheals et al., 2008). It would be very important simultaneously to use for these goals non-food agricultural resources. Such an approach, besides other advantages linked with necessity to use food resources for the wellbeing of our planet's population, would decrease also the cost of final products. Therefore, it has become interesting to use waste products and residues of agriculture, forestry and wood-processing industry to substitution oil. Such material has also a very low price, making it very efficient from the economical point of view (Dale et al., 2014). At the same time the processing of lignocellulosic material into ethanol and chemicals also has serious difficulties. They are linked with lignocellulose recalcitrance to biological conversion. Therefore, a special pretreatment stage is necessary to overcome these problems. There have been many studies performed during the last decades that were devoted to this problem (see review by Taherzadeh and Niklasson, 2004; Taherzadeh and Karimi, 2008; Shafiei et al., 2015, etc.). Many pretreatment procedures have been proposed, and in general all of them are directed to make lignocellulose more acceptable for the enzymatic hydrolysis (Wyman et al., 2005; Taherzadeh and Karimi, 2008; Karimi et al., 2013). For this goal it is necessary to provide the possibility of efficient contacts of enzymes and lignocellulose surface. This depends on the total surface area of lignocellulosic particles as well as on their porosity and capillary structure (Karimi et al., 2013).

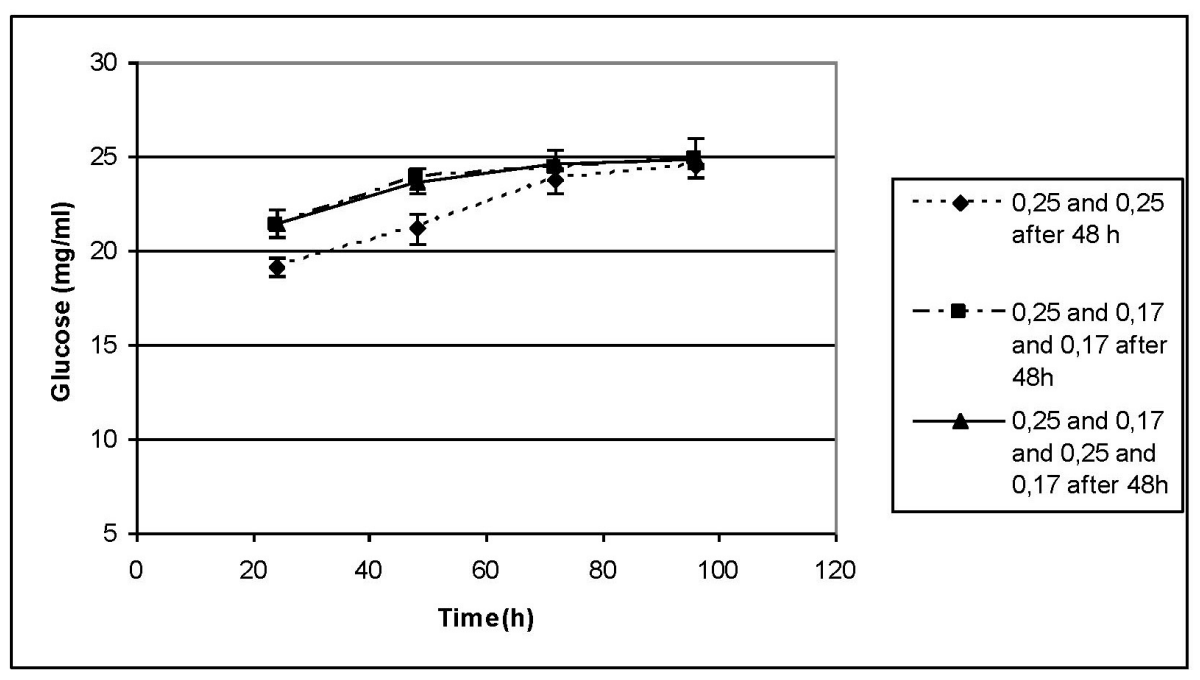

Fig. 1. Glucose yield after enzymatic hydrolysis with extra addition of enzymes after 48 hours of hydrolysis. 
The approach used in our research, which is based on the fundamental works of $\mathrm{N}$. Vedernikov and his colleagues, has becomes the most challenging (Rapoport et al., 2014). First, it provides a means of development of waste-less technologies, which would provide a possibility to produce sequentially two main compounds that can substitute oil as a resource for the chemical industry and production of fossil fuel - furfural and ethanol. Second, the first necessary pretreatment of lignocellulosic material is used not only for the "opening" of this substrate for its further enzymatic hydrolysis, but is simultaneously the method for the production of furfural. It is necessary to mention here that almost $95 \%$ of all synthetic materials produced presently by the chemical industry from oil can be obtained from furfural and ethanol. It is supposed that ethanol will be mainly used as the alternative to fossil fuels and therefore only furfural will become a real alternative to oil as a chemical raw material in the near future.

The results obtained in this study showed that first our pre-treatment simultaneously produced a high amount of furfural (about $72 \%$ of the theoretically possible) and very efficiently changed the structure of lignocellulose, which "opened" it for further enzymatic hydrolysis. Our research showed that the optimum temperature for hydrolysis of our material is $50{ }^{\circ} \mathrm{C}$. At these conditions the use of one main enzyme (Accellerase 1500) was sufficient. If other temperatures for hydrolysis were applied or smaller concentrations of the main enzyme were used, the addition of enzyme Accellerase XC was very efficient and gave high yield of glucose at temperatures other than optimum and in the case of applications of lower amounts of the main enzyme than optimum. The final decision on the conditions that should be applied in each concrete case should be taken, of course, on the basis of additional economical calculations. Our calculations showed that the glucose yield that was reached in these experiments was about $76.5 \%$ of the theoretically amount. Taking into account the large amounts of crystalline cellulose in wheat straw, which is not usually well hydrolysed by enzymes, we suppose that at present a rather good result was obtained. Most probably it was possible to decrease significantly the amount of crystalline cellulose by increasing the ratio of its amorphous form by the pretreatment. We suppose also that the enzymes we used were effective also against at least part of crystalline LC. Of course, in further experiments it would be necessary to attempt to increase additionally the amounts of final products. In general, our results show the efficiency of the used pre-treatment at the stage of furfural production, for further enzymatic hydrolysis. The results showed efficiency of the use of Accellerase 1500 and Accellerase XC for the treatment of wheat straw with the goal to develop waste-less technology for the production of furfural and ethanol chemicals which can substitute oil.

\section{ACKNOWLEDGMENTS}

This work has been supported by the European Regional Development Fund project

No. 2014/0026/2DP/2.1.1.1.0/14/APIA/VIAA/002.

\section{REFERENCES}

Balat, M. (2007). Global bio-fuel processing and production trends. Energy Explor. Exploit., 25, 195-218.

Ballesteros, I., Negro, M. J., Oliva, J. M., Cabanas, A., Manzanares, P., Ballesteros, M. (2006). Ethanol production from steam-explosion pretreated Wheat Straw. Appl. Biochem. Biotechnol., 496, 129-132.

Bhat, M. K., Bhat, S., (1997). Cellulose degrading enzymes and their potential industrial applications. Biotechnol. Adv., 15, 583-620.

Calinescu, I., Chipurici, P., Trifan, A., Bădoiu, C. (2012). Immobilisation of Saccharomyces cerevisiae for the production of bioethanol. UPB Sci. Bull., 74, 33-40.

Dale, B. E., Anderson, J. E., Brown, R. C., Csonka, S., Dale, V. H., Herwick, G., Jackson, R. D., Jordan, N., Kaffka, S., Kline, K. L., Lynd, L. R., Malmstrom, C., Ong, R. G., Richard, T. L., Taylor, C., Wang, M. Q. (2014). Take a closer look: Biofuels can support environmental, economic and social goals. Environ Sci. Technol., 48 (13), 7200-7203.

Escobar, L. M. A., Alvarez, U. S., Penuela, M., (2012). Continuous production of ethanol in packed bed-bioreactors with immobilized yeast cells on lignocellulosic waste. Dyna, 174, 107-113.

Govindaswamy, S., Vane, L. M. (2007). Kinetics of growth and ethanol production on different carbon substrates using genetically engineered xylose-fermenting yeast. Bioresource Technol., 98, 677-85.

Grad, P. (2006). Biofuelling Brazil: An overview of the bioethanol success story in Brazil. Refocus, 7, 56-59.

Hendriks, A., Zeeman, G. (2009). Pretreatments to enhance the digestibility of lignocellulosic biomass. Biores. Technol., 100, 10-18.

Juhász, T., Szengyel, Z., Roczey, K., Siika-Aho, M., Viikari, L. (2005). Characterization of cellulases and hemicellulases produced by Trichoderma reesei on various carbon sources. Process Biochem., 40, 3519-3525.

Karimi K., Shafiei M., Kumar R. (2013). Progress in physical and chemical pretreatment of lignocellulosic biomass. In: Gupta, V. K., Tuohy, M. G. (eds.). Biofuel Technologies. Springer, Berlin, pp. 53-96.

Kerr, R. A. (1998). The next oil crisis looms large and perhaps close. Science, 281, 1128-1131.

Kim, S., Dale, B. E. (2004). Global potential bioethanol production from wasted crops and crop residues. Biomass Bioenergy, 26, 361-375.

Ladisch, M. R., Dyck, K. (1979). Dehydration of ethanol: New approach gives positive energy balance. Science, 205 (4409), 898-900.

Linoj Kumar, N. V., Dhavala, P., Goswami, A., Maithel, S. (2006). Liquid biofuels in South Asia: Resources and technologies. Asian Biotechnol. Develop. Rev., 8, 31-49.

Malca, J., Freire, F. (2006). Renewability and life-cycle energy efficiency of bioethanol and bio-ethyl tertiary butyl ether (bioETBE): Assessing the implications of allocation. Energy, 31, 3362-3380.

Mosier, N., Wyman, C., Dale, B., Elander, R., Lee, Y. Y., Holtzapple, M., Ladish, M. (2005). Features of promising technologies for pretreatment of lignocellulosic biomass. Biores. Technol., 96, 673-686.

Neelakandan, T., Usharani, G. (2009). Optimisation and production of bioethanol from Cashew apple juice usingi yeast cells by Saccharomyces cerevisiae. Amer. Eurasian J. Sci. Res., 4 (2), 85-88.

de Oliveria, M. E. D., Vaughan, B. E., Rykiel, Jr., E. J. (2005). Ethanol as fuel: Energy, carbon dioxide balances, and ecological footprint. BioScience, 5, 593-602.

Ortiz, R., Sayre, K. D., Govaerts, B., Gupta, R., Subbarao, G. V., Ban, T., Hodson, D., Dixon, J. M., Ivan Ortiz-Monasterio, J., Reynolds, M. (2008). Climate change: Can wheat beat the heat? Agricult. Ecosyst. Environ., 126, 46-58.

Rapoport, A., Vedernikov, N., Kruma, I., Puke, M., Borovikova, D., Rozenfelde, L., Khroustalyova, G., Matyuskova, N. (2014). Waste-less bioethanol and other valuable substances production from hardwood. WIT Transact. Eng. Sci., 88, 311-317. 
Shafiei, M., Kumar, R., Karimi, K. (2015). Pretreatment of lignocellulosic biomass. Springer International. In: Karimi, K. (Ed.). LignocelluloseBased Bioproducts. Springer International Publishing, Switzerland, pp. 85-154.

Taherzadeh, M. J., Niklasson, C. (2004). Ethanol from lignocellulosic materials: Pretreatment, acid and enzymatic hydrolyses and fermentation. In: Saha, B. C., Hayashi, K. (eds.). Lignocellulose Biodegradation. American Chemical Society, Washington, DC, pp. 49-68.

Taherzadeh, M. J., Karimi, K. (2007). Enzyme based hydrolysis processes for ethanol from lignocellulosic materiāls: A review. BioResources, 2 (4), $707-738$.

Received 27 August 2015

Accepted in the final form 26 July 2017
Taherzadeh, M. J., Karimi, K. (2008). Pretreatment of lignocellulosic wastes to improve ethanol and biogas production: A review. Int. J. Mol. Sci., 9 (9), 1621-1651.

Van Dyk, J. S., Pletschke, B. I. (2012). A review of lignocellulose bioconversion using enzymatic hydrolysis and synergistic cooperation between enzymes: Factors affecting enzymes, conversion and synergy. Biotechnol. Adv., 30, 1458-1480.

Vedernikovs, N. (2008). Method for furfural and bioethanol common production. Latvian patent Nr. 13676 (giving out 20.07.2008).

Wyman, C. E., Dale, B. E., Elander, R. T., Holtzapple, M., Ladisch, M. R., Lee, Y. Y. (2005). Coordinated development of leading biomass pretreatment technologies. Biores. Technol., 96 (18), 1959-1966.

Wheals, A. E., Bassoc, L. C., Alves, D. M. G., Amorim, H. V. (2009). Fuel ethanol after 25 years. Trends Biotechnol., 17, 482-487.

\section{LIGNOCELULOZES ENZIMĀTISKĀ HIDROLĪZE BIOETANOLA RAŽOŠANĀ}

Darbā tika izpētīta temperatūras, laika un izmantotā enzīma daudzuma ietekme uz kviešu salmu lignocelulozes, kas iegūta pēc furfurola atdalīšanas, hidrolīzi. Priekšapstrādātais substrāts tika pakḷuts enzimātiskajai hidrolīzei pie dažādām temperatūrām $-45^{\circ} \mathrm{C}, 50{ }^{\circ} \mathrm{C}$ un $55^{\circ} \mathrm{C}$. Hidrolīzes laiks bija līdz 72 stundām, un paraugi glikozes daudzuma noteikšanai tika ņemti ik pēc 24 stundām. Maksimālais glikozes iznākums (76,5\% no teorētiski iespējamā) tika sasniegts, kad hidrolīzes temperatūra bija $50{ }^{\circ} \mathrm{C}$. Palielinoties hidrolīzes laikam, pieauga arī glikozes daudzums paraugos. Glikozes iznākums bija ievērojami atkarīgs no izmantojamā substrāta un enzīma daudzuma attiecības. 